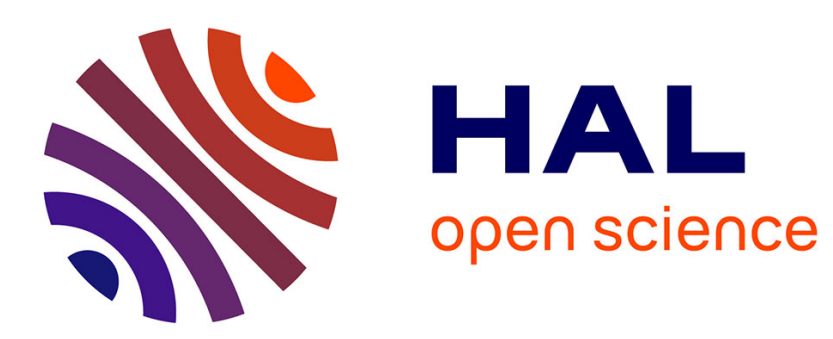

\title{
Electrical resistivity of some liquid cadmium antimony alloys as a function of temperature
}

\author{
J.G. Gasser, R. Kleim
}

\section{To cite this version:}

J.G. Gasser, R. Kleim. Electrical resistivity of some liquid cadmium antimony alloys as a function of temperature. Journal de Physique Lettres, 1975, 36 (4), pp.93-95. 10.1051/jphyslet:0197500360409300 . jpa-00231164

\section{HAL Id: jpa-00231164 https://hal.science/jpa-00231164}

Submitted on 1 Jan 1975

HAL is a multi-disciplinary open access archive for the deposit and dissemination of scientific research documents, whether they are published or not. The documents may come from teaching and research institutions in France or abroad, or from public or private research centers.
L'archive ouverte pluridisciplinaire HAL, est destinée au dépôt et à la diffusion de documents scientifiques de niveau recherche, publiés ou non, émanant des établissements d'enseignement et de recherche français ou étrangers, des laboratoires publics ou privés. 


\title{
ELECTRICAL RESISTIVITY OF SOME LIQUID CADMIUM ANTIMONY ALLOYS AS A FUNCTION OF TEMPERATURE
}

\author{
J. G. GASSER and R. KLEIM
}

Laboratoire de Physique des Milieux Condensés

Faculté des Sciences, Ile du Saulcy, 57000 Metz, France

(Reçu le 3 janvier 1975, accepté le 24 janvier 1975)

\begin{abstract}
Résumé. - La résistivité électrique de quelques alliages $\mathrm{Cd}_{1-x} \mathrm{Sb}_{x}$ riches en antimoine a été mesurée entre la courbe du liquidus et $900^{\circ} \mathrm{C}$ environ. La forte décroissance de la résistivité en fonction de la température au-dessus du point de fusion est interprétée par la présence d'agrégats. $\mathrm{Au}$-dessus de $800^{\circ} \mathrm{C}$ la résistivité devient une fonction croissante de la température.

Abstract. - The electrical resistivity of several $\mathrm{Cd}_{1-x} \mathrm{Sb}_{x}$ antimony rich alloys has been investigated between the liquidus curve and about $900^{\circ} \mathrm{C}$. The sharp decrease in the resistivity, which occurs after the melting point, is discussed in terms of clusters. Above $800^{\circ} \mathrm{C}$, the resistivity becomes an increasing function of temperature.
\end{abstract}

1. Introduction. - The electrical resistivity of $\mathrm{Cd}_{1-x} \mathrm{Sb}_{x}$ alloys has been investigated by Miller Paces and Komarek [1] over the composition range from pure cadmium to 40 at $\%$ cadmium $(x=0$ to 0.6$)$ and at temperatures not exceeding $540^{\circ} \mathrm{C}$. A few other measurements are available : Matuyama [2] $\left(x=0.1\right.$ to 0.80 and $\left.t<700^{\circ} \mathrm{C}\right)$, Oleari and Fiorani [3] $\left(x=0.17\right.$ to 0.85 and $\left.t<590^{\circ} \mathrm{C}\right)$. Enderby and Walsh [4], Busch and Güntherodt [5] have only studied the composition CdSb. It is the aim of this letter to extend the measurements to high temperatures (up to $900^{\circ} \mathrm{C}$ ) for the antimony rich alloys for which few measurements are available.

2. Measurements. - Resistivity measurements were performed by the four probes method, using a quartz cell fitted with carbon coated tungsten electrodes, and by passing direct or low frequency current through the liquid. A pressure of argon up to 7 bars could be applied over the liquid, thereby allowing reliable measurements to be made above the cadmium boiling point $\left(760^{\circ} \mathrm{C}\right)$ by suppressing the appearance of bubbles. Furthermore, these can be detected by small variation of the applied pressure. If this variation provokes an appreciable apparent change in resistance, the presence of bubbles must be suspected.

The precision of the electrical measurements is better than $1 \%$. The main error arises from the uncertainty in composition, because of possible evaporation of a certain amount of the most volatile compound $(\mathrm{Cd})$. The resulting error in composition is estimated to be less than $1 \%$.
The variations of the resistivity as a function of temperature are shown in figure 1 , and the numerical values of the temperature coefficient $\mathrm{d} \rho / \mathrm{d} T$ are recorded in table I.

Our results are in good agreement with those of the authors cited previously (ref. [1] to [4]), but for CdSb

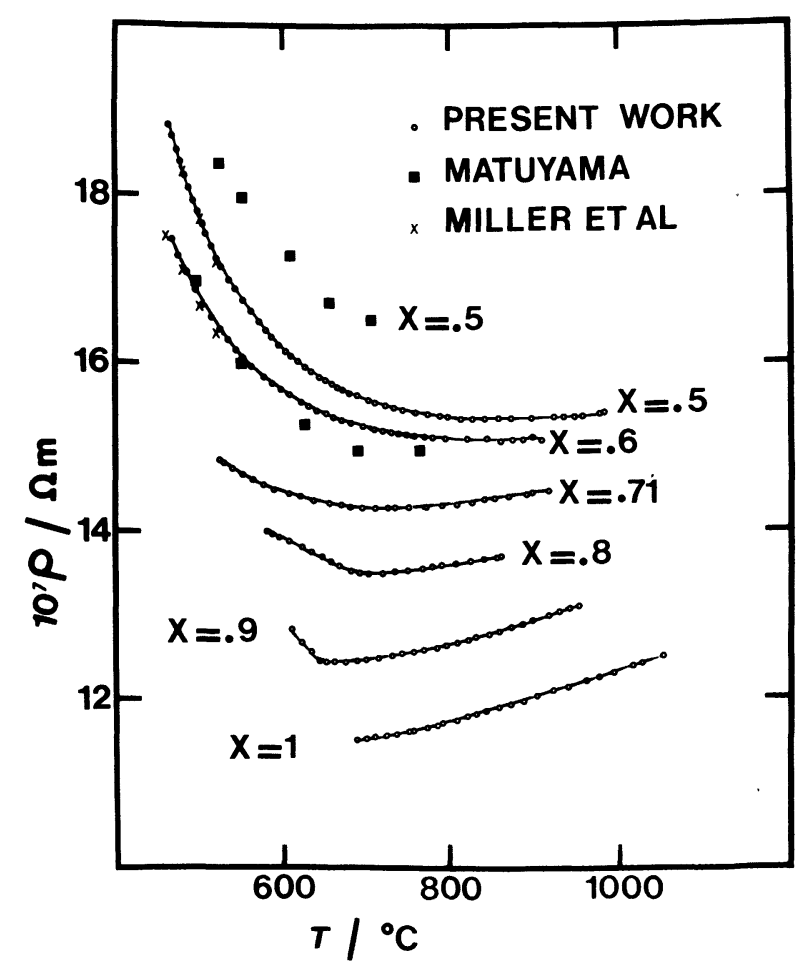

Fig. 1. - Electrical resistivity of $\mathrm{Cd}_{1-x} \mathrm{Sb}_{x}$ alloys as a function of temperature. 
TABLE I

Temperature coefficient of the resistivity as a function of composition $\left(10^{-11} \Omega . \mathrm{m} . \mathrm{K}^{-1}\right)$

$\begin{array}{ccccc}\text { Composition } & \text { Temperature } \\ \frac{\mathrm{Sb}}{\mathrm{Sb}} & -500^{\circ} \mathrm{C} & 500 & 550 & 600 \\ \mathrm{Cd}_{10} \mathrm{Sb}_{90} & & & - & \\ \mathrm{Cd}_{20} \mathrm{Sb}_{80} & & & & -8 \\ \mathrm{Cd}_{29} \mathrm{Sb}_{71} & & & -54 & - \\ \mathrm{Cd}_{40} \mathrm{Sb}_{60} & & -180 & -104 \\ \mathrm{Cd}_{50} \mathrm{Sb}_{50} & -310 & -260 & -140\end{array}$

we do not find the strong increase above $630^{\circ} \mathrm{C}$ quoted in [5].

Near the melting point, the temperature coefficients are negative with high absolute values $\left(-30 \times 10^{-10} \Omega . \mathrm{m} . \mathrm{K}^{-1}\right)$. They remain negative up to $800^{\circ} \mathrm{C}$ for the compositions $x=0.5$ and $x=0.6$, and only near the vicinity of the liquidus temperature for $0.7 \leqslant x \leqslant 0.9$. If the temperature is sufficiently high, they tend to become positive for all compositions.

3. Discussion. - The interpretation of the negative temperature coefficient of liquid cadmium antimony alloys is a very controversed problem. Miller Paces and Komarek [1] explained their data by assuming that the short range order is sufficiently extensive to permit retention of some sort of band structure. On the other hand, Enderby and Walsh [4], Enderby and Collings [6] believe that the Faber Ziman [7] theory is the most useful starting point for discussing this type of alloys. As suggested by Bradley, Faber, Wilson and Ziman [8] and Busch and Güntherodt [5], a negative temperature coefficient may appear if $2 k_{\mathrm{F}} \simeq k_{\mathrm{P}}$, where $k_{\mathrm{F}}$ is the Fermi wave vector and $k_{\mathrm{P}}$ is the position of the main peak of the partial or total structure factor. For $\mathrm{Cd}_{1-x} \mathrm{Sb}_{x}$ we may calculate the free electron value of $2 k_{\mathrm{F}}$ from the experimental density [9] and the assumption that $\mathrm{Cd}$ and $\mathrm{Sb}$ provide two and five electrons respectively. The values obtained in this way are located between $2 k_{\mathrm{F}}=3.10 \AA^{-1}$ (for $x=0.5$ ) and $2 k_{\mathrm{F}}=3.36 \AA^{-1}$ for pure antimony.

The partial structure factors are not known but for pure antimony [10] and pure cadmium [11] we have respectively $k_{\mathrm{P}}=2.20 \AA^{-1}$ and $k_{\mathrm{P}}=2.57 \AA^{-1}$.

If we make the reasonable assumption that $k_{\mathrm{P}}$ for $\mathrm{Cd}_{1-x} \mathrm{Sb}_{x}$ is located between these two values, we always have $2 k_{\mathrm{F}}>k_{\mathrm{P}}$.

Thus it is by no means obvious that in this case the negative temperature coefficient may be explained by using the previous arguments, although it cannot be excluded if the real value of $k_{\mathrm{F}}$ is shifted to lower values as has been assumed by Busch and Güntherodt [12] on the basis of experimental Hall coefficient.

In addition, Itami and Shimoji [13] pointed out that negative temperature coefficients may occur if the mean electron number per atom is less or equal to two : this, which in fact is equivalent to $k_{\mathrm{P}} \simeq 2 k_{\mathrm{F}}$, is obviously not the case for $\mathrm{Cd}_{1-x} \mathrm{Sb}_{x}$.
As it can be seen from table I, the decrease of the resistivity is very strong, compared to typical values of other binary systems : $-1.6 \times 10^{-10} \Omega . \mathrm{m} . \mathrm{K}^{-1}$ for CuSn [14] and $-3 \times 10^{-11} \Omega . m . K^{-1}$ for AgSn [5, 14].

A somewhat higher value, of the order of $-8 \times 10^{-10} \Omega . \mathrm{m} \cdot \mathrm{K}^{-1}$ occurs in FeGe alloys [15] but in this case structural grouping or clustering is always possible [16].

In order to explain the high negative temperature coefficient, we suggest that clusters may be present and that they are progressively decomposed as the temperature is raised.

As has been emphasized by Hodgkinson [17, 18, 19], clusters may play a predominant role in liquid alloys. In the case of $\mathrm{Cd}_{1-x} \mathrm{Sb}_{x}$, this hypothesis is strongly supported by the work of Schick and Komarek [20] on the heat capacity of $\mathrm{Cd}_{1-x} \mathrm{Sb}_{x}$ alloys. At temperatures below $580^{\circ} \mathrm{C}$, their data may be interpreted by the presence of $\mathrm{Cd}_{4} \mathrm{Sb}_{3}$ clusters. Moreover, Kumar and Sivaramakrishnan [21] demonstrated that a dispersion of $\mathrm{Cd}_{4} \mathrm{Sb}_{3}$ clusters exists in the liquid. From their data, the percentage volume fraction of clusters is $2 \%$ at $600{ }^{\circ} \mathrm{C}$ and $0.9 \%$ at $650 \% \mathrm{C}$. The cluster hypothesis is also supported by the study of the thermodynamic properties, especially partial molar entropy, reported by Geffken, Komarek and Miller [22].

Unfortunately, the effect of clusters on the transport properties has not yet, to our knowledge, been examined intensively on a theoretical basis, except in a few special cases [23].

For high antimony concentrations $(x>0.8)$ the cluster effect must be less pronounced because of the more elevated liquidus temperature. Above $650^{\circ} \mathrm{C}$, after clustering has almost disappeared, the temperature variation may be explained by the Faber Ziman theory but the lack of the partial structure factors does not allow to say more. For pure antimony our results are in good agreement with those published elsewhere $[24,25,26]$. The resistivity has been calculated by Waseda and Susuki [10] at two temperatures by using their own neutron diffraction results. The values calculated by means of Faber Ziman theory are in reasonable agreement with the measured resistivity, but the temperature coefficient is four times smaller than the experimental value. 


\section{References}

[1] Miller, E., Paces, J. and Komarek, K. L., Trans. A.I.M.E. [15] Busch, G., Güntherodt, H. J., Künzi, H. U., Meier, H. A. 230 (1964) 1557.

[2] Matuyama, Y., Sci. Rept. Tohoku Univ. 16 (1927) 447.

[3] Oleari, L. and Fiorani, M., Ric. Sci. 29 (1959) 2589.

[4] Enderby, J. E. and WaLSh, L., Phil. Mag. 14 (1966) 991.

[5] Busch, G. and Güntherodt, H. J., Phys. Kond. Mater. 6 (1967) 325 .

[6] Enderby, J. E. and Collings, E. W., J. Non-Cryst. Solids 4 (1970) 161

[7] Faber, T. E. and Ziman, J. M., Phil. Mag. 11 (1965) 153.

[8] Bradley, C. C., Faber, T. E., Wilson, E. G. and Ziman, J. M., Phil. Mag. 7 (1962) 865.

[9] Fisher, H. J. and PhILliPs, A., Trans. A.I.M.E. 200 (1954) 1060.

[10] Waseda, Y. and Susuki, K., Phys. Stat. Sol. B 47 (1971) 581.

[11] North, D. M. and Wagner, C. N. J., Phys. Lett. 30A (1969) 440.

[12] BusCh, G. and GüNtherodt, H. J., Adv. Phys. 16 (1967) 651.

[13] Itami, T. and Shimoji, M., Phil. Mag. 25 (1972) 1361.

[14] Roll, A. and Motz, H., Z. Metallk. 48 (1957) 435.

[16] Dreirach, O., Evans, R., Güntherodt, H. J. and KÜNZı, H. U., J. Phys. F 2 (1972) 709.

[17] Hodgkinson, R. J., Phil. Mag. 22 (1970) 1187.

[18] Hodgkinson, R. J., Phil. Mag. 23 (1971) 673.

[19] Hodgkinson, R. J., Proceedings 5th Inter. Conf. Amorphous Liquid Semiconductors, Garmisch Partenkirchen (1973) 841.

[20] Schick, G. and KomareK, K. L., Z. Metallk. 65 (1974) 112.

[21] Kumar, R. and Sivaramakrishnan, C. S., J. Mat. Sci. 6 (1971) 48

[22] GefFKen, R., KomareK, K. L. and Miller, E., Trans. A.I.M.E. 239 (1967) 1151.

[23] Cohen, M. H. and SAK, J., J. Non-Cryst. Solids 8-10 (1972) 696

[24] Roll, A. and Motz, H., Z. Metallk. 48 (1957) 272.

[25] TAKeUCHI, S. and ENDo, H., Trans. Japan Inst. Met. 3 (1962) 30.

[26] TSCHIRNER, H. U., Z. Metallk. 60 (1969) 46. 